
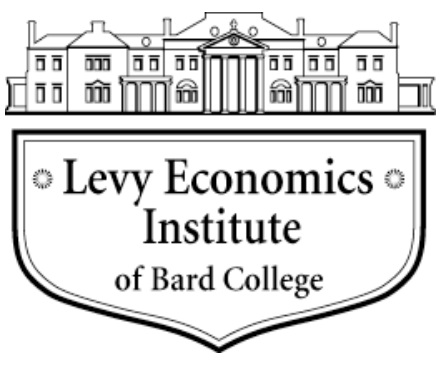

Working Paper No. 823

\title{
The State and National Systems of Innovation: A Sympathetic Critique
}

by

\author{
Giovanna Vertova* \\ University of Bergamo
}

December 2014

*University of Bergamo, Via dei Caniana 2, 24127 Bergamo, Italy. E-mail: giovanna.vertova@unibg.it

This paper was prepared for the project "Financing Innovation: An Application of a Keynes-SchumpeterMinsky Synthesis," funded in part by the Institute for New Economic Thinking, INET grant no. IN012-00036, administered through the Levy Economics Institute of Bard College. Co-principal investigators: Mariana Mazzucato (Science Policy Research Unit, University of Sussex) and L. Randall Wray (Levy Institute). The author thanks INET and the Levy Institute for support of this research.

The Levy Economics Institute Working Paper Collection presents research in progress by Levy Institute scholars and conference participants. The purpose of the series is to disseminate ideas to and elicit comments from academics and professionals.

Levy Economics Institute of Bard College, founded in 1986, is a nonprofit, nonpartisan, independently funded research organization devoted to public service. Through scholarship and economic research it generates viable, effective public policy responses to important economic problems that profoundly affect the quality of life in the United States and abroad.

Levy Economics Institute P.O. Box 5000

Annandale-on-Hudson, NY 12504-5000

http://www.levyinstitute.org

Copyright (C Levy Economics Institute 2014 All rights reserved 


\begin{abstract}
This paper starts with a review of the literature about National Systems of Innovation (NSI), by linking the origin of the concept to the evolutionary theory of the firm and innovation. The first point reviews the flaws of the NSI concept by looking at the pioneering works of Chris Freeman, Bent-Åke Lundvall, and Richard Nelson. These authors' definitions of NSI contain some striking aspects: (1) the definitions are so broad that they can encompass almost everything; (2) although all definitions share the central role played by institutions, the state and its policy are not explicitly mentioned; and (3) it is not clear if the NSI concept is a descriptive or a normative tool. The second point we would like to make is that, when the role of the financial system was finally recognized by evolutionary traditions, it was just added as a "new" element within the NSI. The main aim became one of including the financial system within the NSI and looking for the "right" financial system for the "right" type of innovation. After addressing the weaknesses of the conceptualization of the state within the NSI and the difficulty of the evolutionary theory in understanding the financialization of the economy, our third and last point refers to a new way to view innovations. As Mariana Mazzuccato shows, the state has always been a fundamental, though indirect, actor for the development of certain innovations in certain sectors. Yet this is not enough, especially in a period of crisis. The state should direct innovative activities toward more basic and social needs, thus becoming an "innovator of first resort."
\end{abstract}

Keywords: Government Intervention; Innovator of First Resort; National Systems of Innovation; Supply-side Economics

JEL Classifications: B52, O30, O38 


\section{INTRODUCTION}

Innovation and technological change have always been considered engines of growth.

Moreover, before the current crisis broke, during the last decades of increasing international competitions, innovations were considered as the main possible source of firms' worldwide competitiveness. Yet, a growing awareness was related to the fact that firms do not operate on an isolated island (not even for their innovative activities) but, instead, do work in environments which can either boost or harm innovations. The concept of National Systems of Innovation (NSI) is the main theoretical tool attempting to take into account and integrate the importance of the economic environment for firms' possibility to innovate. The NSI can account for two important and interrelated issues. On the one side, it is used to show international differences or similarities in countries' ability to innovate and to be on the technological edge. On the other side, it becomes a normative tool used to give policy suggestions in order to support firms' innovative activities.

In spite of the growing literature on the NSI, this chapter identifies two main flaws. First, an explicit role of the State has been quite neglected, despite the fact that this theoretical tool has been widely used for policy considerations and suggestions. In line with the argument—or rather, the current propaganda — of "less State and more market," an active role of the State (and other public agents) as directly involved in innovation and technological change is missing. Second, one of the new phenomena of the current phase of economic development - the financialization of the economy - has been overlooked. The only way the NSI approach incorporates finance is by looking at the best financial instruments for innovative firms. Yet, the financialization of the economy plays a strong and harmful role that affects innovations by changing firms' corporate governance.

This chapter is divided as follows. The next section speaks about the development of the NSI concept from its early stages. By looking at the definitions of the three pioneering books, some main features of the NSI are presented. Section 3 concentrates on the role played by the State within the NSI, by looking at the way it has been portrayed in the literature, and its connections with mainstream economics. Section 4 looks at the way financial systems have become important elements of the NSI and stresses the point that financialization (in a macro sense) has been overlooked. Section 5 proposes a new and different way the State should 
operate within the NSI, thus becoming an innovator of first resort. Section 6 concludes the chapter.

\section{NSI ORIGIN AND DEVELOPMENT}

The National System of Innovation (NSI) concept had its origins by the end of the 1980s and middle of the 1990s (Freeman 1987, 1988; Lundvall 1988, 1992a; Nelson 1988, 1992, 1993; Pelikan 1988). The collaboration between Chris Freeman, Richard Nelson and Bent-Åke Lundvall in the International Federation of Institutes for Advanced Study (IFIAS) project was crucial for the development of the concept. Yet, the concept could not have been developed without a new notion of firms and innovation, thus positioning itself immediately within the evolutionary tradition. Ever since its beginning, the evolutionary approach rejected all orthodox economic tools: the production function, the hypothesis of perfect rationality and complete information, and technology as a "freely available black box" costly to produce but not to transfer (Nelson and Winter 1974, 1982). Firms are not profit-maximizing agents choosing from a well-defined and exogenously given set of choices. They are, instead, agents dealing with an uncertain environment, especially as far as innovation is concerned. They learn through imperfect adaptation and mistake-ridden discovery, because it is not possible to believe that the best response has already been learned, but rather it is still to be learned. Firms face uncertainty, also due to innovation, and must learn how to deal with it.

To Schumpeter (1912), innovation consists of any of the following: i) introduction of a new good; ii) introduction of a new method of production; iii) opening a new market; iv) conquest of a new source of supply of raw materials or half-manufactured goods; and v) implementation of a new form of organization. Novelty is the key point here. Innovation, therefore, means to look for "something new" without knowing if this "new" will ever be reached, will ever be sold, will ever be profitable. Uncertainty is, therefore, a key feature of the innovation process. Moreover, in the evolutionary approach, novelty streams from new knowledge, thus making innovation an interactive social learning process. Only when new knowledge is created can innovation flourish. Knowledge contains two dimensions: a "public" one, taking the shape of information easily codified in patents, blueprints, textbooks, etc.; and a "tacit" one, embodied in routines, skills, competencies, and specific practices (Nelson and Winter 1982, chapter 4; Polanyi 1967). The public aspect is costly to create but costless to 
transfer or to make available to others once it has been created. By contrast, the tacit one is not so easily transferred, being the result of different learning processes: learning by doing, by using, by searching, by imitation, by interaction, and by cooperation (Howells 2002). Due to this tacit aspect, new knowledge and innovations are partially context-specific and localized, thus calling for the introduction of geographical aspects. When the geographical distance is negligible, and the language and culture are common, the tacit aspects are easier to transfer. Thus, an interaction between space and innovation occurs, with the development of concepts such as national, regional, and local systems of production.

Despite some references to the work of Friderick List, as the forerunner of the concept (Freeman 1995), the NSI literature developed mostly from the end of the 1980s to the middle of the 1990s, with the aim to understand differences in technological development and profiles of technological specialization among countries. At that time, there were three pioneering books: "Technology Policy and Economic Performance: Lessons from Japan by Freeman (1987)"; "National Systems of Innovation: Towards a Theory of Innovation and Interactive Learning," edited by Lundvall (1992a); and "National Innovation System: A Comparative Analysis," edited by Nelson (1993). We are well aware that a growing body of literature developed after these three books were published. Nevertheless, those three started the NSI literature tradition, thus giving the "standard" to the following studies. (McKelvey (1991) includes Porter in her survey, despite the fact that Porter never explicitly or implicitly spoke about NSI. That is our reason not to include this latter author in our analysis.)

By looking at these authors' definitions, some aspects are striking (Table 1). First, they all share institutional aspects: the NSI is embedded and/or encompasses institutions and/or the institutional set-up of the economy. Yet, drawing from the "old" and "new" institutional economics, the evolutionary tradition uses a very broad concept of institutions, encompassing almost everything: "They encompass not only simply organizations - such as corporations, banks and universities - but also integrated and systematic social entities such as money, language and law" (Hodgson 1998, p. 179). Habits, rules, customs, traditions, social conventions and norms are all institutions. Therefore and consequently, if institutions are everything, anything that impacts on "institutions" will also affect the NSI. Such broad definitions are rarely useful in identifying the NSI key elements and the features affecting them. The NSI concept becomes such a broad one that it can explain almost everything, and that 
means nothing. Moreover, they can foster the idea that anything-meaning all aspects of a nation (social, political, legal, cultural, etc.)—-must revolve around firms' ability to innovate.

\section{Table 1 Some NSI Definitions}

Freeman (1987, p. 1)

Over the last two centuries those scientific and technical activities which are intended to promote the flow of technical and organisational innovations and their diffusion have vastly increased in scale and have become highly specialised in a variety of institutions. At the same time national education and training systems, which may both encourage and disseminate advances in technology, have expanded largely to ensure that the labour force has the changing mix of skills needed to diffuse and operate these new techniques efficiently. The network of institutions in the public and private sectors whose activities and interactions initiate, import, modify and diffuse new technologies may be described as 'the national system of innovation'.

The narrow definition would include organisations and institutions involved in

Lundvall (1992, p. 12) searching and exploring - such as R\&D departments, technological institutes and universities. The broad definition [...] includes all parts and aspects of the economic structure and the institutional set-up affecting learning as well as searching and exploring....

There is, first, the concept of a national system of innovation itself. [...] Consider the term "innovation." In this study we interpret the term rather broadly, to encompass the process by which firms master and get into practice

Nelson (1993, p. 4-5) product designs and manufacturing processes that are new to them, if not to the universe or even to the nation. [...] Then there is the term "system." [...] Rather the concept is of a set of institutions whose interactions determine the innovative performance, in the sense above, of national firms. [...] Rather, the "systems" concept is that of a set of institutional actors that, together, plays the major role in influencing innovative performance. 
A second problem with this stream of literature is the confusion related to the aspect of the NSI concept. From both the theoretical and the empirical literature, it is not clear whether the concept is a descriptive or a normative tool. On the theoretical side, by looking at the three books previously mentioned, some insights can be drawn. Freeman has a definite normative approach, which can be captured by the subtitle of the book itself: "Lessons from Japan." The author's task is clearly stated in the Introduction: "This study is about some features of the Japanese system of innovation and their implications for other countries.” (Freeman 1987, p. 1). And, "The book concentrates on the analysis of Japanese experience in the belief that comparative international studies can yield lessons of great importance for policy-makers, whether in the public or the private sector." (Freeman 1987, p. 3). Despite some authors' words of caution about Freeman's awareness that policies and institutions which appear to have worked well in one country cannot be mechanically transferred to a very different social, economic and cultural context, some important social and institutional innovations can be widely and successfully diffused to other countries, albeit with a significant time lag. Lundvall has a more mixed approach. On the one side, the author claims that "one of the main purposes of this book is to contribute to a theoretical understanding of interactive learning and innovation" (Lundvall 1992a, p. 4), thus leading to a descriptive dimension. On the other side, the author carries on by stating that "the concept 'national system of innovation' may also be useful when it comes to inspire public policy at the national and international level" (Lundvall 1992a, p. 4), thus leading to a normative dimension. Nelson has a more definitive descriptive dimension. In a previous article summarizing the main context of his book, Nelson (1992, p. 347) states that "The studies were carefully designed, developed, and written to illuminate the institutions and mechanisms supporting technical innovation in the various countries, the similarities and differences across countries and how these came to be, and to permit at least preliminary discussion of how the differences seemed to matter."

On the empirical side, the literature has been growing and expanding (Balzat and Hanusch 2004). The empirical studies share the same methodological approach: the key elements of an NSI must be identified and, when possible, measured. This literature agreed that the most important elements of any NSI are the following: innovative firms; public and private institutions conducting and supporting research and promoting the diffusion of knowledge and innovation; the systems of education and training of the personnel; and financial systems (which were added later, as discussed in the next section). For each of these components, statistical data 
are collected and used as proxies to measure all NSI elements, thus allowing international comparisons, leading to the search for "the best" NSI used as a benchmark for other countries (Patel and Pavitt 1994). So, the theoretical tool becomes a normative one, with strong policy suggestions, immediately adopted by policymakers (OECD 1988, 1997).

\section{THE STATE WITHIN THE NSI}

As demonstrated, the NSI literature, especially the studies with a descriptive approach, share attempts to identify, and consequently, where possible, measure the most important NSI elements. Taking for granted that innovative firms are the core actors, other agents, organizations and institutions are crucial for firms' innovative ability. Again, going back to the three pioneering books previously cited, the key elements are clearly identified. By looking at the Japanese system, Freeman (1987, p. 4) decides to focus his attention on some specific aspects. "The analysis concentrates on four main features of the system: 1. the role of the Ministry of International Trade and Industry (MITI), 2. the role of company research and development strategy in relation to imported technology and 'reverse engineering', 3. the role of education and training and related social innovations, and 4. The conglomerate structure of industry".

Lundvall (1992a, p. 13) lists the elements of the systems: "international organization of firms, interfirm relationship, role of public sector, institutional set-up of the financial sector, R\&D intensity and R\&D organization.” Nelson $(1992,1993)$ identifies the following major institutional actors: firms and industrial research laboratories, universities and government laboratories; government financial support (that means public money) for R\&D in industry; the national system of schooling and training; and financial institutions. By combining these approaches with the more recent literature (Groenewegen and van der Steen 2006; Shafir 2006), a typical ideal NSI is formed by the innovative firms, the core of the system, interacting among themselves and also with others (clients and suppliers) through user-producer relationships (Lundvall 1992b).

Furthermore, firms also interact with non-market agents, such as the external environment encompassing organizations and institutions. First of all, firms interrelate with institutions and organizations - such as universities, technological institutions and public research laboratories - involved in the generation and development of basic scientific research 
as well as the training of scientists and engineers. Second, firms depend upon national education systems and labor markets, because schooling, training and retraining not only determine the supply of skills of the labor force but also influence the attitudes of workers toward technical change. Third, firms need a proper institutional setup, encouraging them to innovate. Competition in markets as well as intellectual property rights (in a broad sense) must be guaranteed. Finally, the financial system must be geared toward the best way to finance innovative activities, which are uncertain and costly.

Although all the previous definitions share an institutional approach, where institutions are key elements of the NSI, the State is never explicitly mentioned. In fact, states and governments do not appear as explicit elements of NSI. Nevertheless, some of its policies do, although in the background. Fiscal policies are implicitly suggested by the normative approach, when policy suggestions recommend the creation and support of a "friendly" environment in order to foster firms' ability to innovate. Therefore, universities, technological institutions, and public research laboratories must interact with firms in order to support and help them to innovate. Universities play an extremely important role in technical advance and knowledge creation, not only as places where industrial scientist and engineers are trained, but also as the source of research findings and techniques considered to be relevant to innovation in industries (Industry and Innovation 2006).

Moreover, national education systems must be geared to the needs of firms' innovative activities, by creating a skilled labor force at all levels of education. A more educated labor force can develop new technologically useful knowledge through various kinds of learning processes. Furthermore, the State must intervene as a regulator in order to guarantee the existence of proper market competition (despite the so-called "Schumpeterian hypothesis" stating that big firms, and therefore, monopoly markets, have the better chance to innovate) and the possibility for innovative firms to appropriate the results of their R\&D activities (with, for example, the legal protection of intellectual property rights). Most of these government interventions are part of fiscal policy, because they are possible only with public expenditures. Nevertheless, fiscal policies are never explicitly mentioned in the analysis, although they are indirectly called for in relation to the creation of physical and social infrastructure needed by innovative firms.

Also monetary policy is generally overlooked, being hardly mentioned as an NSI element. The problematic issue of financing innovation has been acknowledged later in the 
evolutionary tradition (see the next section). It seems surprising that a tradition spurred by Schumpeter initially overlooked the matter. Schumpeter was, in fact, the first to draw a strong connection between innovations and the credit system, with the banker being the "capitalist par excellence" (Schumpeter 1912). The banking (and the financial system) create the "purchasing power" that enables firms to carry out innovative activities. Therefore, if and how investments in innovation are financed depends also on monetary policy, which, in turn, affects the banking and financial system of a nation.

The State comes, indirectly, into an NSI only as an "institution" whose task is to supply the key elements for creating and maintaining a favorable environment for firms' innovative activities. The State must only supply and adjust the "proper" physical and social infrastructures, in order to enhance firms' ability to innovate. Thus, government policy toward innovation is relegated to a regulative task, leaving private capitalist firms to deal with innovations. The State must create and maintain competitive market structures in order to let firms compete among themselves, so that the most innovative will survive.

This normative dimension of an NSI has three main flaws. First, the regulatory task is relegated to the microeconomic environment (i.e., industrial policy, technology policy, and the supply of physical and social infrastructures, etc.). It seems that the macroeconomic dimension, also shaped by government policy, is not taken into proper consideration when innovation is concerned. Second, due to this strong supply orientation of the NSI normative dimension, some of its elements are geared toward firms' innovative activities, although they should have very different social tasks. A good example relates to universities. Most literature stresses the point that universities must interact with firms, in order to either create new knowledge that firms can use or to interact with them to develop and implement innovation, or must act as a private firm, and thus become academic entrepreneurs (Economics of Innovation and New Technology, 2012). Nevertheless, universities should have a different social task: offer higher education to the population, in order to create well-educated citizens.

Finally, the NSI normative dimension with its supply-side orientation finds a strong theoretical background in orthodox/mainstream economics, revived in the last decades. Monetarism and supply-side economics restored the faith in self-regulating markets, with the idea that private capitalist firms are the only economic agents able to create wealth, growth and employment (the so-called "trickle down effects"). The normative NSI dimension states the same: private capitalist firms are considered to be the best and only agents of innovative 
activities. The quantity and the quality of private firms' innovations are never questioned, because it is implicitly assumed that they are beneficial, neglecting any kind of considerations for innovations with negative externalities (i.e., pollution). Moreover, it is never explicitly mentioned that innovative activities of private capitalist firms are driven by profit expectations, which can be pursued regardless of the social consequences (i.e., military industry, genetically modified foods, etc.).

\section{FINANCIAL SYSTEMS AND NSI}

Innovative activities do have costs: basic research, production, commercialization and marketing are all costly activities. Consequently, one of the most important prerequisites for innovative processes is the possibility to finance them. Although innovations are often financed internally, especially in large firms (medium and small ones have less possibilities for selffinancing), higher R\&D costs and shorter life cycles have been making firms more dependent on external finance. Schumpeter was one of the first economists to stress that "credit is primarily necessary to new combinations" (Schumpeter 1912). Schumpeter's essential point is that new combinations (i.e., innovations) in production and in products could not appear without being financed. Therefore, finance and development are in a symbiotic relationship.

Moreover, according to the Austrian economists, money is never neutral and the credit mechanism, managed by bankers and financiers, is necessary to development. So, the national financial system becomes an NSI crucial element. National financial systems impact on the borrower-lender relationship, which is characterized by asymmetric information and uncertainty. This latter can be reduced by the type of relationships between the borrower (in this case, firms) and the lender (in this case, banks and financial institutions). Different channels used to obtain capital and money create distinctive relationships between lenders and borrowers, which may or may not reduce uncertainty. So, the institutional setup of national financial systems may foster or harm innovations.

Almost from the beginning of the development of the NSI concept, the literature focused on a theoretical description of the financial system, in order to understand its effects on firms' innovative performance (Dosi 1990; Tylecote 1994). From the very beginning, two stylized financial systems were distinguished: the "bank-based" (or "credit-based") and the "stockexchange-based" (or "market-based"). The former is where a small number of large firms are 
public companies quoted on the stock market, and even these companies do not rely heavily on it as a source of funds. Instead, they use banks as their main source of external funding. So, in this system, the relationship between firms and banks is "relational" (Tylecote 1994, p. 261): each loan is seen as part of a long-term relationship where, on the one side, the firm is willing to give the bank full information about its performance and plans; and, on the other side, the bank is committed to supporting the firm even through bad times. This kind of financial system can be found in some continental European countries, and in Japan, Korea and Taiwan.

The latter is formed by quoted firms which look at the stock market as a major source of equity and other finance. In this system, banks are not used to obtaining finance for innovations and investment plans. The relationship between firms and banks is "transactional" (Tylecote 1994, p. 262) rather than relational: each loan is a one-off. This first and very basic distinction of these two types of financial systems was enriched by the acknowledgment of the role of the State. So Christensen (1992) proposes a new classification based on two criteria: the relative importance of financial markets and financial institutions on the one side, and the role of government with its regulation on the other. In this way the author (1992, p. 153) identifies three types of financial systems:

“a) a market oriented system, where funds are allocated through a developed capital market with perfect competition and little government influence; b) a credit based system, where financial institutions - mainly banks - transfer savings to investments and with heavy government control and regulation and c) a credit based system dominated by financial institutions with little government intervention" (Christensen 1992).

This new taxonomy takes into consideration the regulative task of governments in the banking systems.

As soon as the financial system was considered to bear an important contribution to innovation, it was added as a "new" element within the NSI. The financial system has been analyzed as a sum of different financial instruments, with the main aim to find which of them is the "right" one for different types of innovations. So, for example, using the first rough distinction just mentioned, it has been shown that a bank-based system is better for long-term investment and innovations while a stock-exchange-based one is better for costly and risky innovations (Tylecote 1994). Yet, again, the descriptive analysis translates immediately into a normative tool, taken up also by policy makers (OECD 2012). And again, the supply-side orientation is clear. In order to establish framework conditions that foster investment in R\&D 
and innovation, governments must use a variety of instruments (i.e., subsidies loans, tax incentives, public support to venture capital, etc.). The OECD (2012, p. 161) states that "Promoting investment in innovation through greater access to finance remains an issue across the OECD. The problem is how to increase and broaden the sources of public and private financing for innovation, $[\ldots]$ ”.

The empirical literature has strongly contributed to this supply-side orientation by demonstrating that each financial instrument has varying impact on different kinds of innovations (Brown et al. 2009; Gompers 2002; Hsu et al. 2014). Bank loans tend to be the most common tool for access to finance, though they require collateral and/or guarantees. Grants and subsidies are mostly used by start-up and small and medium-sized enterprises (SMEs) at the seed and early stage. Business angels provide financing at the early riskier stage. Venture capital tends to invest at the later, less risky growth stage. Corporate venturing is generally used by large firms to invest in innovative startups. Crowd funding makes it easier for SMEs to raise capital at the seed and early stage, because it is a tool based on the Internet. Finally, tax incentives are used by most governments.

I argue that this approach is flawed. This is a "micro" approach, which attempts to find the better financial instruments for innovations, according to the characteristics of firms (large, small, product specialization and sectors, age, etc.). This way of looking at the relationship between finance and innovations prevents one from seeing the "macro" aspect of finance, that is the process of the financialization of the economy, that has been going on for quite a while, since before the current crisis, and it impacts firms' innovative activities. Also, thanks to direct interventions of the State and governments (the case of the repeal of the Glass-Steagall Act is an example), financial innovations were invented in order to enable firms (all firms) to make profits through financial markets, rather than through production and innovations. Many heterodox economists underline that financialization emerged as a response to firms' problems in making profits (Arrighi 2010; Brenner 2002; Harvey 2010). The lack of profitable investment opportunities in the real sector led to the search for higher profits in the financial sectors.

Yet, this had a strong impact on innovations for two main and interrelated reasons. First, more and more firms redirected their financial resources toward financial markets, instead of toward production, investment, and innovation. For example, Lazonick and O'Sullivan (2002, p. 33) remark that, in 1998, Intel spent more than twice as much on stock repurchases as on R\&D; and Microsoft's stock repurchases were almost equal to its in-house spending on R\&D. Second, 
it changed the corporate governance of firms. Maximizing shareholder value became the new mantra and led to shareholder pressure, short-termism, downsizing and the allocation of more resources to financial investments, with their negative impacts on innovations. It seems that Minsky's money manager capitalism is quite neglected by the evolutionary tradition (Minsky 1998).

\section{THE STATE AS INNOVATOR OF FIRST RESORT}

Many heterodox economists speak about a new functioning of the capitalist economy, which started by the late 1970s, and called it "neoliberalism" (Saad-Filho and Johnston 2005; Duménil and Lévy 2011). This new model of capital accumulation was created not only by market forces, but was also supported by new political and theoretical (especially economic theory) ideas. The Chicago School of Economics supplied the economic theory, which was a revisited edition of the neo-classical one. Emphases on the efficiency of market competition, the role of individuals in determining economic outcomes, the distortions associated with government intervention and regulation of markets were the main tenets, diffused worldwide by the Chicago Boys. The main characteristics of neoliberalism are:

"a new discipline of labour and management to the benefit of lenders and shareholders; the diminished intervention of the state concerning development and welfare; the dramatic growth of financial institutions; the implementation of new relationship between financial and non-financial sectors, to the benefit of the former; a new legal stand in favour of merges and acquisitions; the strengthening of central banks and the targeting of their activity towards price stability, and the new determination to drain resources of the periphery towards the centre" (Duménil and Lévy 2005, p. 10).

Within this political and theoretical background, the State has a very narrow space in which to operate. Industrial and innovation policies are reduced to what this paper describes in section 3: the State only has to perform a regulative task in order to create a proper and "friendly" environment where private capitalist firms can prosper and innovate. As Mariana Mazzucato (2013) has clearly shown, the dogma of "less State and more market" has not been occurring in reality. By looking at some of the most innovative US industries of the last decades, she shows how the State has been a riskier entrepreneur than private firms, as well as how private firms have relied heavily upon State support. Further, she shows how even more innovative firms have enjoyed a free ride in what she called a parasitic system: a system where 
the private sector is able to take advantages from the State without paying for them. So, in reality, in most cases, the State has played the role of a leading investor, going beyond market and system failures.

Mazzucato's work is very valuable because it clearly demolishes the myth of the efficient private firms vs. the inefficient public ones. Yet, we believe that a step further must be taken. We argue that a new way to look at innovations and at State involvement is necessary, especially in this period of crisis. In order to do that, some qualifications are needed. The first one is related to the heated debate about "private" and "public." The dispute of "private vs. public" is pointless if one takes into consideration that these two types of economic agents have different tasks and goals. Private firms produce and innovate in order to make profits. Because their actions are driven by profit expectations, they can, and most of the time do, neglect the social consequences of their decisions thus leading to negative externalities. The State should have some social goals in mind and should not be influenced by profits expectation but by some higher social considerations.

So, my consideration is that a more interesting discussion should be about market-driven innovations of private firms vs. social-driven innovations by the State (or other public agents). To be clear, the point here is not for the State to just create public knowledge that private firms can use. The point is that the State should first carry out innovations directly (than means creating new knowledge and applying it to production processes in a completely public value chain), and second, address these innovative activities toward more basic social needs, which may be better off in public hands than in free market competition, thus becoming an innovator of first resort. "First" refers to the fact that the innovative State should do something different from what private firms do, having in mind some primary social needs.

Three examples can clarify the point. The most basic need for human beings is the possibility to have healthy nourishment on the table every day. A quick look at today's agricultural industry shows how and to what extent it has become a real business (it is not by chance that the sector's name has been changed to agribusiness), managed by large-scale, industrialized, vertically-integrated firms inventing anything to increase food production. Genetically modified food is one of the innovations of the agribusiness industry, and the debate about its risk for human health has not reached a clear conclusion.

A second important need is to live a healthy life and, in order to do so, a healthcare system is necessary but not sufficient. Drugs and medicines must be there as well. Relying again 
on Mazzucato's work, the US pharmaceutical industry is a typical case of free-riding: Statefunded laboratories have invested in the riskier phase of the innovative process, producing the most radical new drugs; while the big private pharmaceutical companies have preferred to invest in less risky activities, developing variations of existing drugs.

A third essential need is to live in a clean environment. In this case, green technologies and the green revolution are called to mind. The same previous arguments apply here as well. These examples have the goals to question whether it is sensible to leave the State just to regulate these sectors, or to call for a direct and strong State presence.

Moreover, by taking a Keynesian approach, a State as innovator of first resort can also help to exit the current crisis, by creating new jobs for producing and supplying social public goods. Many economists have stressed the importance of an expansionary fiscal policy as the only way out of the crisis. Combining the two could give a desirable outcome of having more social and public goods and employment.

\section{CONCLUSIONS}

In this chapter, we tried to explain the flaws in the theoretical approach of evolutionary thinking regarding the State and its role within the NSI. It seems that both the descriptive and the normative dimensions of the NSI and of the role played by the State give suggestions for public policy which are in line with supply-side economics. Within this framework, the State has no active and direct role to play as far as industrial and innovation policy are concerned; but the State is simply relegated to either reduce market failures or control negative externalities.

This argument is in line with the usual view about the efficiency of private firms vs. the inefficiency of any kinds of public agents. Needless to say there is much ideology and myth about the economic superiority of private firms, as Mazzucato (2013) has clearly pointed out. Moreover, I think that it is not the right time to think and declare the supremacy of private firms, due to the current economic crisis, which was the result of the economic actions of private actors. Yet, this propaganda is difficult to defeat.

The main point I argue in the chapter is that the opposition between the private (efficient firms) and public (inefficient actors) is misplaced: they are different kinds of economic agents, who should have different tasks and goals in mind. And this applies to the creation, diffusion and utilization of new knowledge for technical progress and innovations. So, a more transparent 
distinction should be between market-driven innovations, carried out by private capitalist firms, and social-driven ones, performed by public economic agents.

Therefore, the question is not about the capacity (or incapacity) of the State to pick winners, but the ability of the State to have some social priorities, democratically chosen by a bottom-up approach, and to work on them. The creation, diffusion and utilization of knowledge to industrial processes should have some social needs in mind and should be separated from markets and profits expectations. A Keynesian State, working as innovator of first resort, has more chance to use knowledge and innovation for some crucial social goals. Last but not least, this kind of approach to industrial and innovation policy has a greater possibility to lead us out of the current crisis. 


\section{References}

Arrighi G. (2010), “The Long Twentieth Century: Money, Power, and the Origins of Our Times," London: Verso (new and updated edition.

Balzat M. and Hanusch, H. (2004), "Recent Trends in the Research on National Innovation Systems," Journal of Evolutionary Economics, vol. 14, n. 2, pp. 197-210.

Brenner R. (2002), “The Boom and the Bubble: The U.S. in the World Economy,” New York: Verso.

Brown J.R., Fazzari, S.M., and Petersen, B.C. (2009), "Financing Innovation and Growth: Cash Flow, External Equity, and the 1990s R\&D Boom,” Journal of Finance, vol. 64, n. 1, pp. 151-85.

Christensen, J.L. (1992), “The Role of Finance in National Systems of Innovation,” in Lundvall B-Å. (ed.), National Systems of Innovation. Towards a Theory of Innovation and Interactive Learning. Pinter Publisher (pp. 146-168).

Dosi, G. (1990), "Finance, innovation and industrial change," Journal of Economic Behaviour and Organisation, vol. 13, n. 3, pp. 299-319.

Duménil, G. and Lévy, D. (2005), “The Neoliberal (Counter)Revolution,” in A. Saad-Filho and D. Johnston (eds.), Neoliberalism. A Critical Reader. London and Ann Arbor (MI): Pluto Press (pp. 9-19).

(2011), "The Crisis of Neoliberalism," Cambridge (MA) and London: Harvard University Press.

Economics of Innovation and New Technology (2012), “Academic Entrepreneurship and Economic Competitiveness," special issue, vol. 21, n. 5-6.

Freeman, C. (1987), “Technology Policy and Economic Performance: Lesson from Japan,” Pinter Publisher.

(1988), “Japan: A New National System of Innovation?," in G. Dosi, C. Freeman, R. Nelson, G. Silverberg, L. Soete (eds.), Technical Change and Economic Theory. London and New York: Pinter Publisher (pp. 330-348).

(1995), “The 'National System of Innovation' in Historical Perspective," Cambridge Journal of Economics, vol. 19, n. 1, pp. 5-24.

Gompers, P.A. (2002), "Corporations and the Financing of Innovations: The Corporate Venturing Experience," Federal Reserve Bank of Atlanta Economic Review, vol. 87, n. 4, pp. 1-17. 
Groenewegen, J. and van der Steen, M. (2006), "The Evolution of National Innovation Systems," Journal of Economic Issues, vol. 40, n. 2, pp. 277-285.

Harvey, D. (2010), "The Enigma of Capital and the Crisis of Capitalism," New York and Oxford: Oxford University Press.

Hodgson, G.M. (1998), “The Approach of Institutional Economics,” Journal of Economic Literature, vol. 36, n. 1, pp. 166-192.

Howells, J.R.L. (2002), “Tacit Knowledge, Innovation and Economic Geography,” Urban Studies, vol. 39, n. 5-6, pp. 871-884.

Hsu, P-H., Tian, X., Xu, Y. (2014), "Financial Development and Innovation: Cross-Country Evidence," Journal of Financial Economics, vol. 112, n. 1, pp. 116-135.

Industry and Innovation (2006), University Technology Transfer and National Systems of Innovation, Special issue, vol. 13, n. 4.

Lazonick, W. and O’Sullivan, M. (2000), “Maximizing Shareholder Value: A New Ideology for Corporate Governance," Economy and Society, vol. 29, n. 1, pp. 13-35.

Lundvall, B-Å. (1988), "Innovation as an Interactive Process: From User-producer Interaction to the National System of Innovation," in G. Dosi, C. Freeman, R. Nelson, G. Silverberg, L. Soete (eds.), Technical Change and Economic Theory. London and New York: Pinter Publisher (pp. 349-369).

(1992a, ed.), National Systems of Innovation. Towards a Theory of Innovation and Interactive Learning. Pinter Publisher.

(1992b), "User-producer Relationship, National Systems of Innovation and Internationalization," in B- $\AA$ Lundvall (ed.), .), National Systems of Innovation. Towards a Theory of Innovation and Interactive Learning. Pinter Publisher (pp. 45-67).

Mazzucato, M. (2013), “The Entrepreneurial State: Debunking Public vs. Private Sector Myths," London: Anthem Press.

McKelvey, M. (1991), "How do National Systems of Innovation Differ?: A Critical Analysis of Porter, Freeman, Lundvall and Nelson," in G.M. Hodgson and E. Screpanti (eds.), Rethinking Economics. Markets, Technology and Economics Evolution. Aldershot: Edward Elgar (pp. 117-137).

Minsky, H.P. (1998), “Schumpeter: Finance and Evolution,” Hyman P. Minsky Archive, Paper 314.

Nelson R. (1988), "Institutions Supporting Technical Change in the United States," in G. Dosi, C. Freeman, R. Nelson, G. Silverberg, L. Soete (eds.), Technical Change and Economic Theory. London and New York: Pinter Publisher (pp. 312-329). 
(1992), "National Innovation Systems: A Retrospective on a Study," Industrial and Corporate Change, vol. 1, n. 2, pp. 347-374.

(1993, ed.), "National Innovation Systems: a Comparative Analysis,” Oxford University Press.

Nelson, R. and Winter, S. (1974), "Neoclassical vs. Evolutionary Theories of Economic Growth: Critique and Prospectus,” Economic Journal, vol. 84, n. 336, pp. 886-904. (1982), “An Evolutionary Theory of Economic Change,” Cambridge Mass.: Harvard University Press.

OECD (1988), New Technologies in the 1990s, Paris.

(1997), National Innovation Systems, Paris.

(2012), Science, Technology and Industry Outlook, Paris.

Patel, P. and Pavitt, K. (1994), "National Innovation Systems: Why They are Important, and How they Might be Measured and Compared," Economics of Innovation and New Technology, vol. 3, n. 1, pp. 77-95.

Pelikan, P. (1988), "Can the Imperfect Innovation Systems of Capitalism be Outperformed?," in G. Dosi, C. Freeman, R. Nelson, G. Silverberg, L. Soete (eds.), Technical Change and Economic Theory. London and New York: Pinter Publisher (pp 370-398).

Polanyi, M. (1967), “The Tacit Dimension,” London: Routledge \& Kegan Paul.

Saad-Filho, A. and Johnston, D. (2005, eds.), “Neoliberalism. A Critical Reader,” London and Ann Arbor (MI): Pluto Press.

Schumpeter, J.A. (1912), “The Theory of Economic Development,” Cambridge, MA: Harvard University Press.

Shafir, N. (2006), "Emergence and Development of the National Innovation Systems Concept," Research Policy, vol. 35, n. 5, pp. 745-766.

Tylecote, A. (1994), "Financial Systems and Innovation," in M. Dodson and R. Rothwell (eds.), The Handbook of Industrial Innovation, Elgar (pp. 259-267). 